\title{
GROWTH AND MORPHOLOGICAL RESPONSES TO IRRADIANCE IN THREE FOREST UNDERSTORY SPECIES OF THE $\mathrm{C}_{4}$ GRASS GENUS MUHLENBERGIA ${ }^{1}$
}

\author{
MARIAN SMITH ${ }^{2}$ AND CRAIG E. MARTIN \\ Department of Botany, University of Kansas, Lawrence, Kansas 66045
}

\begin{abstract}
Three species of the $\mathrm{C}_{4}$ grass genus Muhlenbergia-M. frondosa, $M$. sobolifera, and $M$. schreberiwere collected from forest understory sites in northeastern Kansas and grown in a growth chamber at 1,500, 150 , and $15-25 \mu \mathrm{mol} \mathrm{m} \mathrm{m}^{-2} \mathrm{~s}^{-1}$ photosynthetic photon flux density (PPFD). Leaf, stem, root, and total biomasses and several morphological and anatomical characteristics were measured after 35-38 days. Results were compared with similar measurements for $M$. cuspidata collected from exposed prairie sites. Although all species grew maximally at the highest PPFD, $M$. sobolifera grew equally well at medium PPFD. Few anatomical changes were correlated with changes in PPFD except leaf thickness, which increased with increasing PPFD. The results indicate that, while the understory species of Muhlenbergia can adjust morphologically to some extent to shaded environments, they produce more biomass at higher PPFD.
\end{abstract}

\section{Introduction}

Most $\mathrm{C}_{4}$ plants are restricted to hot, dry, and sunny environments (TEERI and STOWE 1976; DoLINER and JOLLIFFE 1979; TIESZEN et al. 1979; TEERI et al. 1980), but recent findings indicate that the $\mathrm{C}_{4}$ syndrome may not impose an inherent limitation on the ability of a plant to adjust to a wide range of light levels and temperatures (BROWN 1977; PEARCY et al. 1982; WINTER et al. 1982; LONG 1983). Several Euphorbia $\mathrm{C}_{4}$ species adjust photosynthetically to a wide range of light environments in a Hawaiian tropical forest (PEARCY et al. 1982). The $C_{4}$ grass species Microstegium vimineum grows in shady habitats and does not exhibit severe reduction in biomass production at $18 \%$ full sunlight, in contrast to two $\mathrm{C}_{4}$ species from exposed habitats (WINTER et al. 1982). Thus, M. vimineum is more shade adapted than all other $\mathrm{C}_{4}$ species examined thus far. Other $\mathrm{C}_{4}$ species are often reported growing in tropical (RUNDEL 1980), as well as temperate (BROwN 1977), forest understories. Despite this potential for shade adaptation in $\mathrm{C}_{4}$ plants, no comprehensive studies have included comparisons of growth characteristics of closely related shade- and sun-adapted $\mathrm{C}_{4}$ species grown under the range of light environments in which they naturally occur.

Reports indicate that all of the species of the genus Muhlenbergia are $\mathrm{C}_{4}$ plants (DownTON 1971, 1975; GutierRez et al. 1974; HatTERSLEY and BROWNING 1981). At least three species grow in

\footnotetext{
${ }^{1}$ Abbreviations: ANCOVA, analysis of covariance; DMF, N,N-dimethyl formamide; FAA, formalin-acetic acid-alcohol; IRW, initial rhizome weight; LA, total leaf area; LDW, leaf dry weight; LN, leaf number; LSD, least significant difference; PPFD, photosynthetic photon flux density; RDW, root dry weight; SDW, stem dry weight; TDW, total dry weight.

${ }^{2}$ Current address and address for correspondence and reprints: Division of Science and Mathematics, Black Hills State College, Spearfish, South Dakota 57783.

Manuscript received July 1986; revised manuscript received November 1986.
}

the understory of deciduous forests in eastern Kansas: $M$. frondosa in habitats that vary from open, sunny ditches to heavily shaded understory; $M$. sobolifera only in densely shaded forest understory; and $M$. schreberi mostly in disturbed areas in an intermediate light environment (GREAT PLAINS FlORA AsSOCIATION 1986). To understand better the potential for shade tolerance in $\mathrm{C}_{4}$ plants, the growth responses of these species were compared with those of a closely related species, $M$. cuspidata, which is confined to high-light environments.

\section{Material and methods}

Populations of Muhlenbergia frondosa (Poir.) Fern. and M. sobolifera (Muhl.) Trin. were sampled from two locations in the understory of an oakhickory forest (WeLLS and MORLEY 1964) in the Breidenthal Tract of Baldwin Woods, $14 \mathrm{~km} \mathrm{~S}$ of Lawrence, Kansas (Douglas Co.). Muhlenbergia frondosa rhizomes were collected along a $200-\mathrm{m}$ transect of an abandoned railway bed. Levels of PPFD beneath a mixed canopy of hardwood saplings (Quercus spp., Fraxinus americana, Celtis occidentalis, and Carya ovata) varied from less than $150 \mu \mathrm{mol} \mathrm{m} \mathrm{m}^{-2} \mathrm{~s}^{-1}$ under the canopy to full sunlight in open areas at midday.

Rhizomes of $M$. sobolifera were collected from a site ca. $100 \mathrm{~m}$ from a railway bed on a steep, moist bank above a stream. Plants grew among several understory species, including Adiantum pedatum, Sanicula canadensis, and Thuidium delicatulum. Several large trees (Quercus rubra, $Q$. $a l b a$, and Ulmus rubra) shaded the population, resulting in PPFD levels of ca. $10-25 \mu \mathrm{mol} \mathrm{m}^{-2} \mathrm{~s}^{-1}$, but transitory sunflecks were abundant throughout the day.

Muhlenbergia schreberi Gmel., located beneath a canopy of Juniperus virginiana along a small creek, was collected along an unpaved road $0.5 \mathrm{~km}$ NW of Alma, Kansas (Wabaunsee Co.). The PPFD levels ranged from 300 to $1,500 \mu \mathrm{mol} \mathrm{m} \mathrm{m}^{-2} \mathrm{~s}^{-1}$. 
Muhlenbergia frondosa and $M$. sobolifera begin growth in their natural habitats in late May after the canopy is full. Both species flower in September and October, in contrast to the sympatric $\mathrm{C}_{3}$ species which produce leaves in April and flower in June and July. Muhlenbergia schreberi, however, produces a basal leaf of ca. $1 \mathrm{~cm}$ after anthesis, which lasts throughout the winter.

Muhlenbergia cuspidata (Torre.) Rydb. was collected from an open prairie $1.6 \mathrm{~km} \mathrm{E}$ of Hiattville, Kansas (Linn Co.), where it occurred in dense clumps in cracks and at the edges of limestone outcrops. Nearby species included Sedum pulchellum and a mixture of grasses and sedges.

On September 15, 1985, 60 plants of each species were collected and potted the following day. Shoots were clipped from rhizomes, which were weighed and planted in standard greenhouse potting soil. Each $11 \times 11-\mathrm{cm}$ plastic pot contained five plants. Four pots of each species were placed under each of three PPFD levels: ca. 1,500, 150, and $15-25 \mu \mathrm{mol} \mathrm{m} \mathrm{m}^{-2} \mathrm{~s}^{-1}$. The plants at highest PPFD were rotated every day to ensure equal exposure of all plant parts to the light. Plants were well watered, and every pot was given $50 \mathrm{~mL}^{1} / \mathrm{s}^{-}$ strength nutrient solution (HOAGLAND and ARNON 1938) every other day. Light was provided by $400-$ W metal halide lamps. The lower PPFD levels were achieved by using gray plastic window screen. PPFD levels were measured with a LI-COR (Lincoln, Neb.) LI-190SB quantum sensor and LI-198B meter.

Plants were grown in a Sherer growth chamber with a 12 -h photoperiod at $30 / 25 \mathrm{C}$ and $15 \% / 25 \%$ day/night relative humidities. Temperature and humidity were continuously monitored with a hygrothermograph.

After 35-38 days, plants were harvested. Adhering soil was gently washed from roots and rhizomes. Height was measured, LN counted, and LA determined with a LI-COR LI-3000 portable area meter. Plant parts were oven-dried at $85 \mathrm{C}$ for 30 60 days, cooled in a desiccator, and weighed. All growth data were statistically analyzed using ANCOVA (SPSS ${ }^{x}$ computer statistics package, Chicago, Ill.). Mean differences were tested for LSD (SOKAL and ROHLF 1981). Significant differences were inferred when $P<.05$.

Three to 10 leaf samples from each species and light level were collected for leaf anatomical and morphological analyses. Three $1-\mathrm{cm}$ sections were cut ca. $1 \mathrm{~cm}$ from the leaf tip and treated as follows: one was placed in FAA (JOHANSEN 1940) and preserved for paraffin sections; one was placed in DMF to be cleared for stomatal size and density measurements; and one was placed in chilled water for anatomical measurements.

Leaf sections remained in FAA for 1-2 wk and then were rinsed with water, dehydrated, infil- trated with paraffin, mounted, and stained with toluidine blue (SAKAI 1973). Light micrographs were taken with a Nikon M35S camera mounted on a Zeiss standard microscope.

Leaf sections remained in DMF for 1-2 wk and were then examined at $\times 40$ with an Olympus A2 light microscope. Stomatal density and guard cell dimensions were measured with an ocular micrometer on abaxial and adaxial sides of each leaf section. Density was determined at three locations on each of 3-10 leaves from each treatment; length and width of the stomatal complex were determined for 15 stomata on each leaf.

Fresh sections in water were infiltrated under vacuum and then kept on ice for 1-2 days. Freehand cross sections $(40-50 \mu \mathrm{m})$ were cut with a razor blade and examined under a microscope at $\times 40$. Three measurements were made on one leaf from each of 3-10 plants for leaf thickness, bundle sheath diameter, and interveinal distance.

The anatomical and morphological data were analyzed by one-way ANOVA (SPSS ${ }^{x}$ ), and means were compared for LSD (SOKAL and ROHLF 1981). Significant differences were inferred when $P<.05$.

For all species, the data in the tables are unadjusted values; however, the statistics used adjusted values in ANCOVA. Growth light level was the independent variable; TDW, SDW, LDW, or RDW was the dependent variable; IRW was the covariate. There were no data for $M$. cuspidata at low light since all plants died before harvest.

\section{Results}

\section{GROWTH RESPONSES TO PPFD}

TDW, LDW, SDW, and RDW increased with increasing PPFD in Muhlenbergia frondosa and $M$. cuspidata (table 1). TDW, LDW, and SDW in $M$. sobolifera were greater at high and medium PPFD than at low PPFD, while RDW increased linearly with increasing PPFD. In contrast, $M$. schreberi had greater TDW and SDW at high PPFD than at medium and low PPFD. There was a linear increase in LDW with increasing PPFD, but no change in RDW. The LA and LN values for $M$. schreberi and $M$. cuspidata increased with increasing PPFD (table 2). Both values for $M$. frondosa were greater at high and medium PPFD, whereas in M. sobolifera, neither LA nor LN exhibited a response to increasing PPFD.

\section{StOMATAL SIZE AND DENSITY RESPONSES TO PPFD}

In $M$. frondosa there was no response in stomatal size to PPFD; however, density was greatest at medium PPFD (table 3). There were no changes in stomatal length and density in $M$. sobolifera; change in width was not correlated with PPFD (table 3). Muhlenbergia schreberi is amphistomatous, and neither stomatal length nor width was consis- 
TABLE 1

EFFECTS OF PPFD ON TDW, SDW, LDW, AND RDW IN MUHLENBERGIA

\begin{tabular}{|c|c|c|c|}
\hline Species & $\begin{array}{c}\text { High } \\
1,500 \mu \mathrm{mol} \mathrm{m} \mathrm{m}^{-2} \mathrm{~s}^{-1} \\
\bar{X} \pm \mathrm{SE}\end{array}$ & $\begin{array}{c}\text { Medium } \\
150 \mu \mathrm{mol} \mathrm{m}^{-2} \mathrm{~s}^{-1} \\
\bar{X} \pm \mathrm{SE}\end{array}$ & $\begin{array}{c}\text { Low } \\
15-25 \mu \mathrm{mol} \mathrm{m}^{-2} \mathrm{~s}^{-1} \\
\bar{X} \pm \mathrm{SE}\end{array}$ \\
\hline M. frondosa: & $($ No. $=5)$ & $($ No. $=16)$ & $($ No. $=14)$ \\
\hline TDW (g) & $.53 \pm .09 a$ & $.31 \pm .03 b$ & $.17 \pm .02 c$ \\
\hline$\ldots \ldots \ldots \ldots$ & $.15 \pm .03 a$ & $.09 \pm .01 \mathrm{~b}$ & $.01 \pm .00 c$ \\
\hline LDW $(\mathrm{g})$ & $.16 \pm .14 a$ & $.07 \pm .01 \mathrm{~b}$ & $.01 \pm .00 c$ \\
\hline RDW $(\mathrm{g}) \ldots \ldots \ldots \ldots$ & $.21 \pm .03 a$ & $.15 \pm .01 \mathrm{~b}$ & $.15 \pm .02 c$ \\
\hline M. sobolifera: & $($ No. $=9)$ & $($ No. $=11)$ & $($ No. $=15)$ \\
\hline TDW $(\mathrm{g})$ & $.26 \pm .05 a$ & $.18 \pm .03 a$ & $.19 \pm .02 b$ \\
\hline SDW $(\mathrm{g})$ & $.04 \pm .01 \mathrm{a}$ & $.03 \pm .01 \mathrm{a}$ & $.01 \pm .00 \mathrm{~b}$ \\
\hline LDW $(\mathrm{g}) \ldots \ldots \ldots \ldots$ & $.03 \pm .01 \mathrm{a}$ & $.02 \pm .01 \mathrm{a}$ & $.02 \pm .00 \mathrm{~b}$ \\
\hline RDW $(\mathrm{g}) \ldots \ldots \ldots \ldots$ & $.19 \pm .04 a$ & $.13 \pm .02 b$ & $.16 \pm .01 c$ \\
\hline M. schreberi: & $($ No. $=10)$ & $($ No. $=9)$ & $($ No. $=10)$ \\
\hline TDW $(\mathrm{g})$ & $.19 \pm .06 a$ & $.08 \pm .02 b$ & $.12 \pm .02 b$ \\
\hline SDW $(\mathrm{g}) \quad \ldots \ldots \ldots \ldots$ & $.06 \pm .01 \mathrm{a}$ & $.01 \pm .00 \mathrm{~b}$ & $.01 \pm .01 \mathrm{~b}$ \\
\hline LDW $(\mathrm{g}) \ldots \ldots \ldots \ldots$ & $.03 \pm .00 a$ & $.01 \pm .00 \mathrm{~b}$ & $.00 \pm .01 \mathrm{c}$ \\
\hline RDW (g) & $.10 \pm .02 a$ & $.05 \pm .01 \mathrm{a}$ & $.11 \pm .01 \mathrm{a}$ \\
\hline M. cuspidata: & $($ No. $=4)$ & $($ No. $=9)$ & \\
\hline TDW $(\mathrm{g})$ & $.98 \pm .36 a$ & $.39 \pm .05 \mathrm{~b}$ & $\ldots{ }^{a}$ \\
\hline SDW $(\mathrm{g}) \ldots \ldots \ldots \ldots$ & $.13 \pm .06 a$ & $.02 \pm .01 b$ & $\ldots{ }^{a}$ \\
\hline LDW $(\mathrm{g}) \ldots \ldots \ldots \ldots$ & $.07 \pm .03 a$ & $.02 \pm .00 \mathrm{~b}$ & $\ldots$ \\
\hline RDW $(\mathrm{g}) \ldots \ldots \ldots$ & $.52 \pm .31 \mathrm{a}$ & $.35 \pm .04 b$ & $\ldots{ }^{a}$ \\
\hline
\end{tabular}

NOTE.-Probabilities were calculated from ANCOVA. Only means with different letters differ significantly $(P<.05$, LSD). Sample sizes are in parentheses for each light level for each species. All sample sizes in the same column are identical.

${ }^{a}$ No plants survived.

tently correlated with PPFD (table 4). Abaxial stomatal density increased with increasing PPFD, but adaxial stomatal density was not correlated with PPFD (table 4). The size of the abaxial stomata in $M$. cuspidata, also amphistomatous, did not change in response to PPFD, but stomata were less dense at lower light levels (table 4). Stomata on the adax- ial side of the leaves were longer, but less dense, at the lowest PPFD.

\section{LEAF ANATOMICAL RESPONSES TO PPFD}

All species had Kranz anatomy at all PPFDs and large bundle sheath chloroplasts that were evenly distributed across bundle sheath cells (figs. 1, 2).

TABLE 2

THE EFFECT OF PPFD ON LA AND LN IN MUHLENBERGIA

\begin{tabular}{|c|c|c|c|}
\hline Species & $\begin{array}{c}\text { High } \\
1,500 \mu \mathrm{mol} \mathrm{m} \mathrm{m}^{-2} \mathrm{~s}^{-1} \\
\bar{X} \pm \mathrm{SE}\end{array}$ & 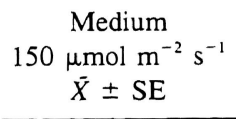 & $\begin{array}{c}\text { Low } \\
15-25 \mu \mathrm{mol} \mathrm{m}^{-2} \mathrm{~s}^{-1} \\
\bar{X} \pm \mathrm{SE}\end{array}$ \\
\hline M. frondosa: & $($ No. $=5)$ & $($ No. $=16)$ & $($ No. $=14)$ \\
\hline $\mathrm{LA}\left(\mathrm{cm}^{2}\right)$ & $40.73 \pm 6.71 \mathrm{a}$ & $39.08 \pm 2.71 \mathrm{a}$ & $12.69 \pm 2.21 b$ \\
\hline LN $\ldots$ & $18.62 \pm 3.44 \mathrm{a}$ & $17.11 \pm 1.12 \mathrm{a}$ & $5.74 \pm .73 b$ \\
\hline M. sobolifera: & $($ No. $=9)$ & $($ No. $=11)$ & $($ No. $=15)$ \\
\hline LA $\left(\mathrm{cm}^{2}\right)$ & $12.99 \pm 3.53 \mathrm{a}$ & $12.54 \pm 3.09 a$ & $11.56 \pm 2.51 \mathrm{a}$ \\
\hline LN $\ldots$. & $8.83 \pm 1.72 \mathrm{a}$ & $7.51 \pm 1.42 \mathrm{a}$ & $6.33 \pm 1.35 \mathrm{a}$ \\
\hline M. schreberi: & $($ No. $=10)$ & $($ No. $=9)$ & $($ No. $=10)$ \\
\hline $\mathrm{LA}\left(\mathrm{cm}^{2}\right)$ & $9.75 \pm 1.18 \mathrm{a}$ & $4.66 \pm .79 b$ & $3.50 \pm .59 c$ \\
\hline LN $\ldots$. & $18.51 \pm 2.63 a$ & $7.02 \pm 1.10 \mathrm{~b}$ & $5.52 \pm .51 c$ \\
\hline M. cuspidata: & $($ No. $=4)$ & $($ No. $=9)$ & \\
\hline LA $\left(\mathrm{cm}^{2}\right)$ & $25.94 \pm 11.63 \mathrm{a}$ & $7.65 \pm 1.48 b$ & $a^{a}$ \\
\hline $\mathrm{LN} \ldots \ldots$ & $36.30 \pm 13.70 \mathrm{a}$ & $7.10 \pm 1.30 b$ &.$^{a}$ \\
\hline
\end{tabular}

NOTE.-Probabilities were calculated from ANCOVA. Only means with different letters differ significantly $(P<.05$, LSD). Sample sizes are in parentheses for each light level for each species. All sample sizes in the same column are identical.

${ }^{a}$ No plants survived. 
TABLE 3

EFFECTS OF PPFD ON STOMATAL SIZE AND DENSITY IN MUHLENBERGIA

\begin{tabular}{|c|c|c|c|}
\hline Species & $\begin{array}{c}\text { High } \\
1,500 \mu \mathrm{mol} \mathrm{m}^{-2} \mathrm{~s}^{-1} \\
\bar{X} \pm \mathrm{SE}\end{array}$ & $\begin{array}{c}\text { Medium } \\
150 \mu \mathrm{mol} \mathrm{m}^{-2} \mathrm{~s}^{-1} \\
\bar{X} \pm \mathrm{SE}\end{array}$ & $\begin{array}{c}\text { Low } \\
15-25 \mu \mathrm{mol} \mathrm{m}^{-2} \mathrm{~s}^{-1} \\
\bar{X} \pm \mathrm{SE}\end{array}$ \\
\hline M. frondosa: & $($ No. $=6)$ & $($ No. $=10)$ & $($ No. $=8)$ \\
\hline Stomatal length $(\mu \mathrm{m})$ & $17.54 \pm .34 \mathrm{a}$ & $17.26 \pm .30 \mathrm{a}$ & $17.65 \pm .30 \mathrm{a}$ \\
\hline Stomatal width $(\mu \mathrm{m})$ & $5.57 \pm .14 \mathrm{a}$ & $5.41 \pm$ & $5.51 \pm$ \\
\hline Stomatal density $\left(\mathrm{mm}^{-2}\right)$ & $349.09 \pm 11.63 \mathrm{a}$ & $373.95 \pm 6.50 \mathrm{~b}$ & $345.95 \pm 14.67 a$ \\
\hline M. sobolifera: & $($ No. $=7)$ & $($ No. $=5)$ & $($ No. $=10)$ \\
\hline Stomatal length $(\mu \mathrm{m})$ & $16.70 \pm .37 \mathrm{a}$ & $16.82 \pm .17 \mathrm{a}$ & $16.76 \pm .36 a$ \\
\hline Stomatal width $(\mu \mathrm{m})$ & $5.93 \pm .06 a$ & $5.33 \pm$ & $5.64 \pm$ \\
\hline Stomatal density $\left(\mathrm{mm}^{-2}\right) \ldots \ldots$ & $407.03 \pm 26.24 a$ & $376.14 \pm 26.18 \mathrm{a}$ & $361.21 \pm 22.72 \mathrm{a}$ \\
\hline
\end{tabular}

NOTE.-Probabilities were calculated from ANOVA. Only means with different letters differ significantly $(P<.05, \mathrm{LSD})$. Sample sizes are in parentheses for each light level for each species. All sample sizes in the same column are identical.

The upper epidermis contained large bulliform cells, and numerous uni- and bicellular microhairs appeared on both abaxial and adaxial leaf surfaces. There was no palisade mesophyll tissue, and the chlorophyllous spongy mesophyll was extremely limited, especially in $M$. cuspidata. The three shade species- $M$. frondosa, $M$. sobolifera, and $M$. schreberi-had chlorophyllous mesophyll cells loosely arranged around the bundle sheaths, with few interstitial chlorophyllous cells. In contrast, $M$. cuspidata had a radial arrangement of chlorophyl- lous mesophyll consisting of elongate cells in a single ring around the bundle sheaths. There were no chlorophyllous cells between the vascular bundles.

Leaf thickness was greatest in all species at the highest PPFD (table 5). The bundle sheaths were largest and farthest apart at high PPFD for all species except $M$. sobolifera, in which these parameters did not correlate with PPFD. In all species, plants grown at high PPFD had the thickest cell walls and most sclerenchyma tissue associated with the vascular bundles.

TABLE 4

EFFECT OF PPFD ON STOMATAL SIZE AND DENSITY IN MUHLENBERGIA

\begin{tabular}{|c|c|c|c|}
\hline Species & $\begin{array}{c}\text { High } \\
1,500 \mu \mathrm{mol} \mathrm{m}^{-2} \mathrm{~s}^{-1} \\
\bar{X} \pm \mathrm{SE}\end{array}$ & 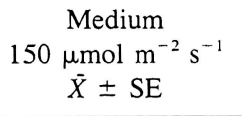 & 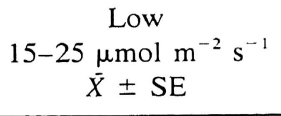 \\
\hline \multirow{2}{*}{\multicolumn{4}{|c|}{$\begin{array}{l}\text { M. schreberi: } \\
\text { Stomatal length }(\mu \mathrm{m}) \text { : }\end{array}$}} \\
\hline & & & \\
\hline Adaxial & $15.62 \pm .23 a$ & $16.74 \pm$ & $15.31 \pm$ \\
\hline Abaxial & $16.36 \pm .30 \mathrm{a}$ & $15.90 \pm$ & $15.47 \pm$ \\
\hline \multicolumn{4}{|l|}{ Stomatal width $(\mu \mathrm{m})$ : } \\
\hline Adaxial $\ldots \ldots \ldots \ldots \ldots \ldots$ & $5.63 \pm$ & $5.74 \pm$ & $5.11 \pm$ \\
\hline Abaxial $\ldots \ldots \ldots$; & $5.48 \pm .09 a$ & $5.32 \pm .12 \mathrm{ab}$ & $5.11 \pm$ \\
\hline \multicolumn{4}{|l|}{ Stomatal density $\left(\mathrm{mm}^{-2}\right)$ : } \\
\hline Adaxial $\ldots \ldots \ldots \ldots$ & $190.46 \pm 10.36 a$ & $126.62 \pm 10.38 b$ & $151.15 \pm 11.34 b$ \\
\hline Abaxial $\ldots \ldots \ldots \ldots$. & $386.46 \pm 8.74 a$ & $358.53 \pm 15.82 b$ & $330.73 \pm 8.34 c$ \\
\hline \multicolumn{4}{|l|}{ M. cuspidata: } \\
\hline \multicolumn{4}{|l|}{ Stomatal length $(\mu \mathrm{m})$ : } \\
\hline Adaxial & $15.88 \pm 1.50 \mathrm{a}$ & $16.66 \pm$ & $18.60 \pm$ \\
\hline Abaxial & $16.57 \pm 1.45 \mathrm{a}$ & $15.84 \pm$ & $15.84 \pm$ \\
\hline \multicolumn{4}{|l|}{ Stomatal width $(\mu \mathrm{m})$ : } \\
\hline Adaxial & $6.27 \pm$ & $6.30 \pm$ & $5.74 \pm$ \\
\hline Abaxial $\ldots$ & $6.44 \pm .07 a$ & $6.10 \pm .35 a$ & $6.68 \pm$ \\
\hline \multicolumn{4}{|l|}{ Stomatal density $\left(\mathrm{mm}^{-2}\right)$ : } \\
\hline Adaxial $\ldots \ldots \ldots \ldots$ & $332.87 \pm 30.09 a$ & $318.90 \pm 6.27 a$ & $239.10 \pm 11.79 b$ \\
\hline Abaxial & $218.58 \pm 7.89 a$ & $208.79 \pm 6.13 a$ & $134.17 \pm 13.61 b$ \\
\hline
\end{tabular}

NoTE.-Probabilities were calculated from ANOVA. Only means with different letters differ significantly $(P<.05$, LSD). Sample sizes are in parentheses for each light level for each species. All sample sizes in the same column are identical. 

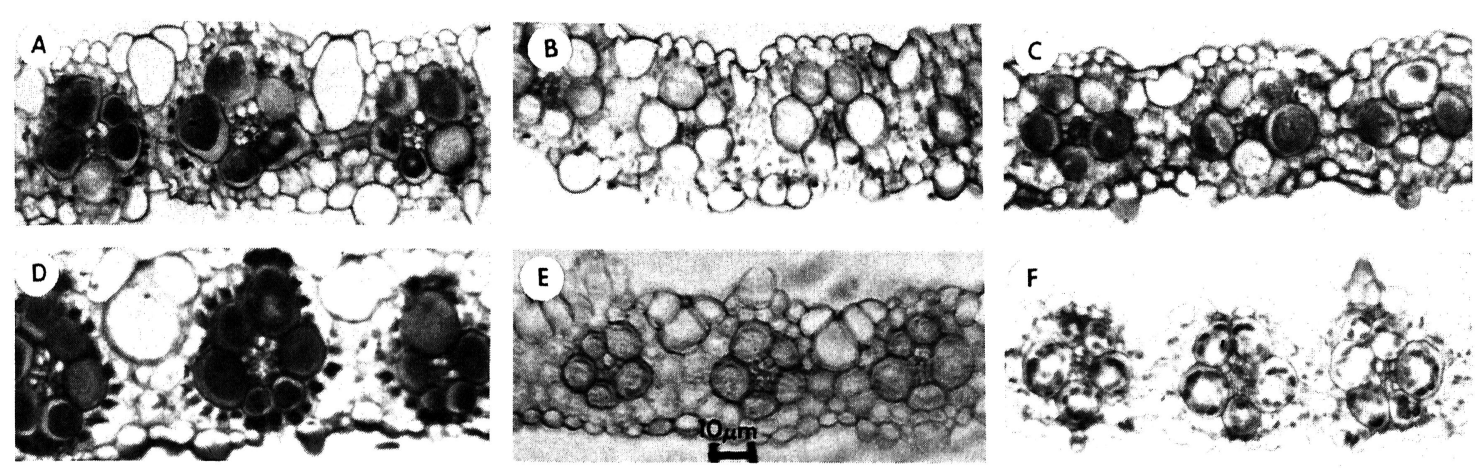

FIG. 1.-Cross sections of leaves of Muhlenbergia frondosa $(A-C)$ and $M$. sobolifera $(D-F)$ grown in a growth chamber at $1,500 \mu \mathrm{mol} \mathrm{m}^{-2} \mathrm{~s}^{-1}(A, D), 150 \mu \mathrm{mol} \mathrm{m} \mathrm{s}^{-2} \mathrm{~s}^{-1}(B, E)$, and $15-25 \mu \mathrm{mol} \mathrm{m}^{-2} \mathrm{~s}^{-1}(C, F)$. Sections are from the first fully expanded leaf of mature plants. All $\times 210$.
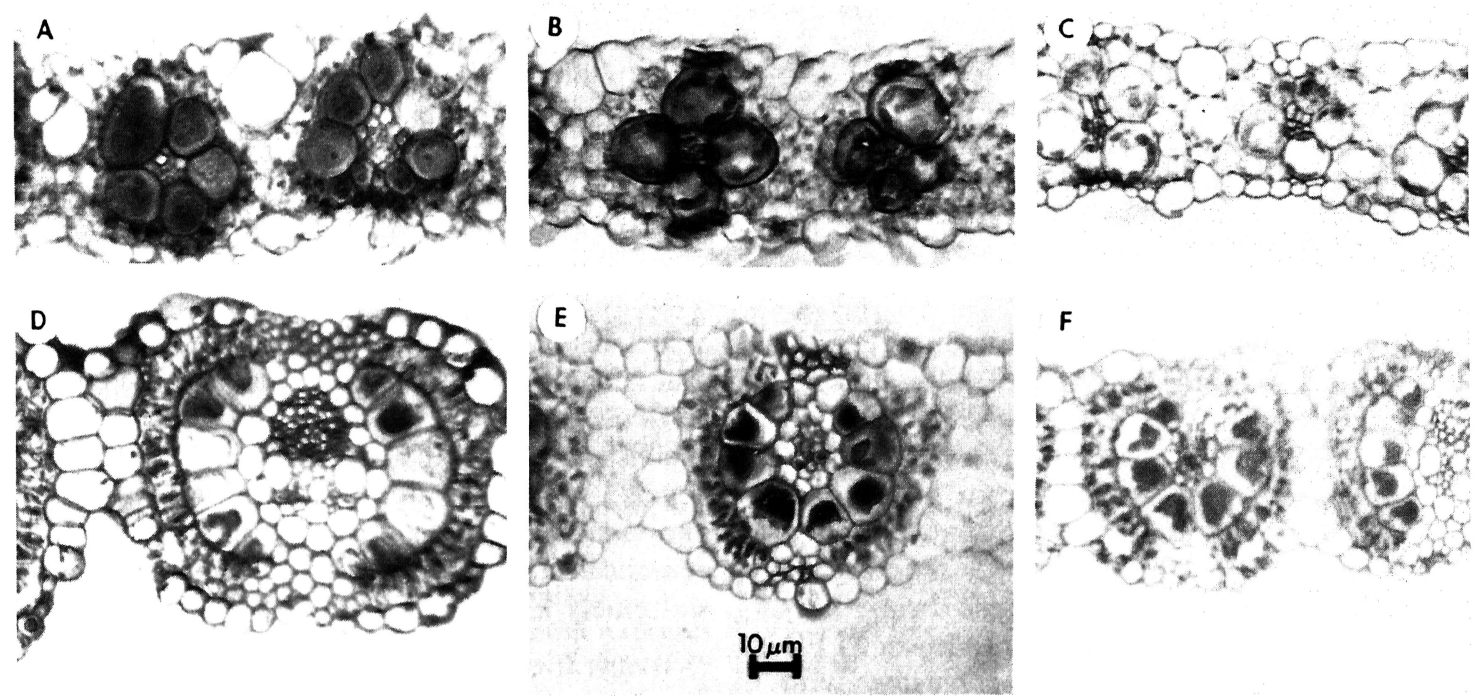

FIG. 2.-Cross sections of leaves of Muhlenbergia schreberi $(A-C)$ and $M$. cuspidata $(D-F)$ grown in a growth chamber at $1,500 \mu \mathrm{mol} \mathrm{m}^{-2} \mathrm{~s}^{-1}(A, D), 150 \mu \mathrm{mol} \mathrm{m}{ }^{-2} \mathrm{~s}^{-1}(B, E)$, and $15-25 \mu \mathrm{mol} \mathrm{m}^{-2} \mathrm{~s}^{-1}(C, F)$. Sections are from the first fully expanded leaf of mature plants. All $\times 225$.

\section{Discussion}

\section{GROWTH RESPONSES TO PPFD}

A preliminary growth experiment, conducted in 1983 , indicated that there was no significant increase in biomass between plants harvested after 30,45 , and 65 days of growth. We infer, therefore, that all plants in this study were vegetatively mature after 35-38 days of growth.

The results clearly indicate that Muhlenbergia cuspidata, found only in open prairies, is a typical $\mathrm{C}_{4}$ species that grows maximally under high PPFD. Not only was biomass, including all of its components, greatest at high PPFD, but the plants failed to survive beyond 30 days at low PPFD. This is consistent with results for other $\mathrm{C}_{4}$ species; e.g., Digitaria sanguinalis and Sporobolus airoides, two $\mathrm{C}_{4}$ grasses characteristic of sunny, open habitats, failed to grow at ca. $100 \mu \mathrm{mol} \mathrm{m} \mathrm{m}^{-2} \mathrm{~s}^{-1}$ (WINTER et al. 1982).

Because two of the species are rhizomatous and two are not, there are interspecific differences between rhizome mass. Although we did not determine the final rhizome fresh weights and are therefore unable to determine relative growth rates, by using initial rhizome weight as a covariate, we were able to determine the effects of growth PPFD by examining the final biomass. Based on the RDW/ TDW ratio, $M$. frondosa, a rhizomatous species, responded in a similar manner to decreased growth PPFD as did M. schreberi, a nonrhizomatous species.

Muhlenbergia frondosa also produced greatest biomass at high PPFD, but, in contrast to M. cuspidata, it survived and grew at low PPFD, indicating some degree of shade tolerance. In $M$. so- 
TABLE 5

EFFECTS OF PPFD ON LEAF THICKNESS, BUNDLE SHEATH WIDTH, AND INTERVEINAL DISTANCE IN MUHLENBERGIA

\begin{tabular}{|c|c|c|c|}
\hline Species & $\begin{array}{c}\text { High } \\
1,500 \mu \mathrm{mol} \mathrm{m} \mathrm{m}^{-2} \mathrm{~s}^{-1} \\
\bar{X} \pm \mathrm{SE}\end{array}$ & $\begin{array}{c}\text { Medium } \\
150 \mu \mathrm{mol} \mathrm{m}^{-2} \mathrm{~s}^{-1} \\
\bar{X} \pm \mathrm{SE}\end{array}$ & $\begin{array}{c}\text { Low } \\
15-25 \mu \mathrm{mol} \mathrm{m}^{-2} \mathrm{~s}^{-1} \\
\bar{X} \pm \mathrm{SE}\end{array}$ \\
\hline M. frondosa: & $($ No. $=5)$ & $($ No. $=8)$ & $($ No. $=7)$ \\
\hline Leaf thickness $(\mu \mathrm{m})$ & $66.4 \pm 6.1 \mathrm{a}$ & $56.2 \pm 5.0 \mathrm{~b}$ & $44.0 \pm 4.6 c$ \\
\hline Interveinal distance $(\mu \mathrm{m})$ & $74.0 \pm 4.8 \mathrm{a}$ & $63.1 \pm 3.6 \mathrm{~b}$ & $59.2 \pm 7.0 \mathrm{bc}$ \\
\hline Bundle sheath width $(\mu \mathrm{m})$ & $49.0 \pm 3.7 \mathrm{a}$ & $40.2 \pm 2.6 b$ & $39.5 \pm 4.5 b c$ \\
\hline M. sobolifera: & $($ No. $=7)$ & $($ No. $=8)$ & $($ No. $=10)$ \\
\hline Leaf thickness $(\mu \mathrm{m})$ & $75.4 \pm 8.0 \mathrm{a}$ & $69.0 \pm 7.5 b$ & $57.6 \pm 6.6 c$ \\
\hline Interveinal distance $(\mu \mathrm{m})$ & $78.0 \pm 9.7 a$ & $62.7 \pm 2.4 b$ & $80.3 \pm 6.8 \mathrm{a}$ \\
\hline Bundle sheath width $(\mu \mathrm{m})$ & $52.1 \pm 6.5 a$ & $38.0 \pm 3.2 b$ & $48.5 \pm 4.3 c$ \\
\hline M. schreberi: & $($ No. $=10)$ & $($ No. $=4)$ & $($ No. $=7)$ \\
\hline Leaf thickness $(\mu \mathrm{m})$ & $78.2 \pm 4.6 \mathrm{a}$ & $59.4 \pm 3.5 b$ & $53.8 \pm 5.4 c$ \\
\hline Interveinal distance $(\mu \mathrm{m})$ & $83.9 \pm 5.2 \mathrm{a}$ & $72.4 \pm 2.1 \mathrm{~b}$ & $71.5 \pm 6.4 b$ \\
\hline Bundle sheath width $(\mu \mathrm{m})$ & $57.9 \pm 4.1 \mathrm{a}$ & $50.3 \pm 3.6 \mathrm{~b}$ & $46.6 \pm 3.6 c$ \\
\hline M. cuspidata: & $($ No. $=4)$ & $($ No. $=5)$ & $($ No. $=2)$ \\
\hline Leaf thickness $(\mu \mathrm{m})$ & $92.6 \pm 8.9 a$ & $85.4 \pm 8.7 b$ & $79.6 \pm 7.8 b$ \\
\hline Interveinal distance $(\mu \mathrm{m})$ & $132.5 \pm 4.4 \mathrm{a}$ & $108.8 \pm 8.0 \mathrm{~b}$ & $106.0 \pm 8.9 b$ \\
\hline Bundle sheath width $(\mu \mathrm{m}) \ldots \ldots \ldots$ & $78.5 \pm 7.0 \mathrm{a}$ & $69.4 \pm 2.9 b$ & $64.8 \pm 4.5 b$ \\
\hline
\end{tabular}

NOTE.-Probabilities were calculated from ANOVA. Only means with different letters differ significantly $(P<$ .05, LSD). Sample sizes are in parentheses for each light level for each species. All sample sizes in the same column are identical.

bolifera, growth was maximized at medium PPFD, an unusual response for a $\mathrm{C}_{4}$ plant. Although $M$. schreberi exhibited a linear decrease in LDW in response to decreasing PPFD, the TDW, SDW, and RDW values remained constant from medium to low PPFD. This response indicated that, although it grows maximally at high PPFD, M. schreberi is more shade tolerant than $M$. frondosa or $M$. cuspidata. RDW decreased in response to lower PPFD in $M$. frondosa and $M$. cuspidata, consistent with the trend in aboveground biomass. However, this trend was not observed in $M$. sobolifera and $M$. schreberi.

Shade plants generally have larger, thinner leaves than sun plants (BOARDMAN 1977; BJÖRKMAN 1981), a morphological adaptation that maximizes the interception of light in shaded environments. Though LN decreased proportionally more than LA from high to medium PPFD in $M$. cuspidata, implying slightly larger leaves under reduced light, the degree of reduction was so severe at both PPFDs that it seems improbable this slight increase in leaf size constitutes an adaptation to shade. Also, this species is unable to survive at the lowest PPFD, indicating that any increase in individual leaf size does not compensate for the overall loss of LA.

Muhlenbergia frondosa and $M$. schreberi exhibited proportionally similar reductions in both LA and LN from high to low PPFD, indicating that there is no increase in individual leaf size. However, $M$. frondosa maintains equal LA under high and medium PPFD, suffering a significant reduction only at low PPFD; and $M$. schreberi, while exhibiting a decrease in LA with decreasing PPFD, maintains enough LA to survive even at low PPFD. Therefore, both species are more shade tolerant than $M$. cuspidata. Muhlenbergia sobolifera maintains a constant LA and LN over the entire range of PPFD levels. While this does not imply an increase in individual leaf size in response to decreasing light, it indicates an ability to maintain leaf area even at extremely low PPFD.

\section{STOMATAL SIZE AND DENSITY RESPONSES TO PPFD}

DENGler (1980) and KNAPP and Gilliam (1985) reported that stomatal density decreased in response to decreasing light level. Other studies reported no change in density in response to light (HOLMGREN 1968; McCONNELL et al. 1984) or even an increase at low light (PAZOUREK 1970). Also, the ratio between the number of stomata on the adaxial and abaxial surfaces of the leaf is greater in plants grown at high light (HOLMGREN 1968) and for $\mathrm{C}_{4}$ plants than for $\mathrm{C}_{3}$ plants (DAS and SANTAKUMARI 1977), but no consistent trend has been demonstrated for stomatal size in sun and shade plants (HOLMGREN 1968; FAILS et al. 1982; MCCONNELl et al. 1984).

Muhlenbergia cuspidata, collected from prairie sites, exhibited greater stomatal density when grown under high light. These results agree with those of KNAPP and GILliAM (1985) for Andropogon gerardii, a $\mathrm{C}_{4}$ prairie grass. However, it may be more significant that $\boldsymbol{M}$. cuspidata is amphistomatous and had a greater number of stomata on the upper surface of its leaves, which was consistent with its status as a plant adapted to high light (HOLMGREN 1968; DAS and SANTAKUMARI 1977). Muhlenber- 
gia schreberi was the only shade species in this study that was amphistomatous, but, in contrast to $M$. cuspidata, it had fewer stomata on the adaxial than on the abaxial leaf surface. Therefore, it is intermediate in respect to stomatal position between $M$. cuspidata and the hypostomatous species $M$. frondosa and $M$. sobolifera. In all species, there were no consistent trends in stomatal size with changing PPFD.

\section{LEAF ANATOMICAL RESPONSES TO PPFD}

Leaf thickness typically decreases with a corresponding decrease in light level (COOPER and Qualls 1967; Holmgren 1968; PazOUREK 1970; KNECHT and O'LEARY 1972; KNAPP and GILLIAM $1985)$ and is often accompanied by increased leaf size (KNECHT and O'LEARY 1972; FAILS et al. 1982). All of the species in this study responded to lower light levels by producing thinner leaves but did not show a consistent increase in size (estimated from LN and LA data, table 2). Bundle sheath width decreased in response to lower light levels in all species, which is consistent with decreased me- sophyll area to leaf surface area (Ames/A) ratios and lower rates of photosynthesis observed for plants grown under low light levels (SMITH and MARTIN, unpublished data). At the same time, the shade species showed a decrease in interveinal distance in plants grown at lower light levels. The shadeadapted $\mathrm{C}_{4}$ grass, Microstegium vimineum, grown at four light levels, exhibited no significant difference in interveinal distance (WINTER et al. 1982).

The significance of the differences in our study is difficult to assess, but we hypothesize that they are a consequence of the longer, narrower leaves produced at low light in $M$. frondosa, $M$. sobolifera, and $M$. schreberi (unpublished data), a phenomenon observed in other grasses (BUBAR and MORRISON 1984).

\section{Acknowledgments}

This investigation was supported by University of Kansas General Research Allocation 3397-X00038 and Biomedical Sciences Support Grant RR07037.

\section{LITERATURE CITED}

BJÖRKMAN, O. 1981. Responses to different quantum flux densities. Pages 57-107 in A. Pirson and M. H. Zimmermann, eds. Encyclopedia of plant physiology. Vol. 12A. Springer, New York.

BOARDMAN, N. K. 1977. Comparative photosynthesis of sun and shade plants. Annu. Rev. Plant Physiol. 28:355-377.

Brown, W. V. 1977. The Kranz syndrome and its subtypes in grass systematics. Mem. Torrey Bot. Club 13:1-97.

BUBAR, C. J., and I. N. MoRrison. 1984. Growth responses of green and yellow foxtail (Setaria viridis and S. lutescens) to shade. Weed Sci. 32:774-780.

COOPER, C. S., and M. Qualls. 1967. Morphology and chlorophyll content of shade and sun leaves of two legumes. Crop Sci. 7:672-673.

Das, V. S. R., and M. SantakUmari. 1977. Stomatal characteristics of some dicotyledonous plants in relation to the $\mathrm{C}_{4}$ and $\mathrm{C}_{3}$ pathways of photosynthesis. Plant Cell Physiol. 18:935-938.

Dengler, N. G. 1980. Comparative histological basis of sun and shade leaf dimorphism in Helianthus annuus. Can. J. Bot. 58:717-730.

Doliner, L. H., and P. A. JollifFe. 1979. Ecological evidence concerning the adaptive significance of the $\mathrm{C}_{4}$ dicarboxylic acid pathway of photosynthesis. Oecologia 38:23-24.

Downton, W. J. S. 1971. Check list of $\mathrm{C}_{4}$ species. Pages 554558 in M. D. Hatch, C. B. Osmond, and R. O. Slatyer, eds. Photosynthesis and respiration. Wiley, New York.

- 1975. The occurrence of $\mathrm{C}_{4}$ photosynthesis among plants. Photosynthetica 9:96-105.

Fails, B. S., A. J. LeWIS, and J. A. BARDEN. 1982. Net photosynthesis and transpiration of sun- and shade-grown Ficus benjamina leaves. J. Am. Soc. Hort. Sci. 107:758-761.

Great Plains Flora Association. 1986. Flora of the Great Plains. University of Kansas Press, Lawrence. 1,392 pp.

Gutierrez, M., V. E. Gracen, and G. E. Edwards. 1974. Biochemical and cytological relationships in $\mathrm{C}_{4}$ plants. Planta 119:279-300.

HatTeRsley, P. W., and A. J. Browning. 1981. Occurrence of the suberized lamella in leaves of grasses of different photosynthetic types. I. In parenchymatous bundle sheaths and
PCR ("Kranz") sheaths. Protoplasma 109:371-401.

HoAgland, D. R., and D. I. ARNon. 1938. The water-culture method for growing plants without soil. Calif. Agric. Exp. Sta. Circ. 347.

HOLMGREN, P. 1968. Leaf factors affecting light-saturated photosynthesis in ecotypes of Solidago virgaurea from exposed and shaded habitats. Physiol. Plant. 21:676-698.

JOHANSEN, D. A. 1940. Plant microtechnique. McGraw-Hill, New York.

Knapp, A. K., and F. S. Gilliam. 1985. Response of Andropogon gerardii (Poaceae) to fire-induced high vs. low irradiance environments in tallgrass prairie: leaf structure and photosynthetic pigments. Am. J. Bot. 72:1668-1671.

KNECHT, G. N., and J. W. O'LeARY. 1972. The effect of light intensity on stomate number and density of Phaseolus vulgaris L. leaves. BOT. GAZ. 133:132-134.

LoNG, S. P. 1983. $\mathrm{C}_{4}$ photosynthesis at low temperatures. Plant Cell Environ. 6:345-363.

McConnell, D. B., P. Rugabar, T. J. Sheehan, and R. J. HENNY. 1984. Light levels alter leaf anatomy of Aphelandra squarrosa 'Dania.' J. Am. Soc. Hort. Sci. 109:298-301.

PAZOUREK, J. 1970. The effect of light intensity on stomatal frequency in leaves of Iris hollandica, var. Wedgewood. Biol. Plant. 12:208-215.

Pearcy, R. W., K. Osteryoung, and D. Randall. 1982. Carbon dioxide exchange characteristics of $\mathrm{C}_{4}$ Hawaiian Euphorbia species native to diverse habitats. Oecologia 55:333341.

RUNDEL, P. W. 1980. The ecological distribution of $C_{4}$ and $C_{3}$ grasses in the Hawaiian Islands. Oecologia 45:354-359.

SAKAI, W. S. 1973. Simple method for differential staining of paraffin embedded plant material using toluidine blue-O. Stain Technol. 48:247-249.

SOKAL, R. R., and F. J. RoHlf. 1981. Biometry. 2d ed. W. H. Freeman, San Francisco. 859 pp.

TeErI, J. A., and L. G. Stowe. 1976. Climatic patterns and the distribution of $\mathrm{C}_{4}$ grasses in North America. Oecologia 23: $1-12$.

Teeri, J. A., L. G. Stowe, and D. A. Livingston. 1980. The distribution of $\mathrm{C}_{4}$ species of the Cyperaceae in North Amer- 
ica in relation to climate. Oecologia 47:307-310.

Tieszen, L. L., M. M. Seniyamba, S. K. Imbamba, and J. H.

Troughton. 1979. The distribution of $\mathrm{C}_{3}$ and $\mathrm{C}_{4}$ grasses and

carbon isotope discrimination along an altitudinal gradient in

Kenya. Oecologia 37:337-350.

Wells, P. V., and G. E. Morley. 1964. Composition of Bald- win Woods: an oak-hickory forest in eastern Kansas. Trans. Kans. Acad. Sci. 67:65-69.

Winter, K., M. R. Schmitt, and G. E. Edwards. 1982. Microstegium vimineum, a shade adapted $\mathrm{C}_{4}$ grass. Plant Sci. Lett. 24:311-318. 